\title{
Polarized Reflectance Spectroscopy
}

National Cancer Institute

\section{Source}

National Cancer Institute. Polarized Reflectance Spectroscopy. NCI Thesaurus. Code

C116483.

An endoscopic technique that uses polarized light to provide qualitative morphological

information of tissue in situ, with reduced background signals, to evaluate epithelial tissue for dysplasia and ischemia. 